\title{
PENYELESAIAN SENGKETA DALAM KONTRAK TAMBANG EMAS MELALUI ARBITRASE
}

\author{
Dominicus Mere \\ Praktisi Pertambangan \\ Korespondensi: dominicus.mere@yandex.com
}

\begin{abstract}
Abstrak
Artikel ini membahas mengenai penyelesaian sengketa dalam kontrak tambang emas melalui arbitrase. UU No. 4 Tahun 2009 menentukan bahwa setiap sengketa yang muncul dalam pelaksanaan izin pertambangan diselesaikan melalui pengadilan dan arbitrase dalam negeri sesuai dengan ketentuan peraturan perundang-undangan. Dalam pembahasan ini penulis berpendapat bahwa pilihan penyelesaian sengketa melalui arbitrase adalah pilihan yang tepat ketimbang pilihan litigasi di pengadilan. Hal tersebut dikarenakan arbitrasi memiliki beberapa kelebihan seperti proses penyelesaian sengketa lebih cepat, hasil kesepakatan yang bersifat "win-win solution", serta jaminan kerahasiaan sengketa dari sorotan publik. Berdasarkan kelebihan- kelebihan tersebut, arbitrase dinilai lebih tepat untuk diterapkan dalam sengketa kontrak tambang emas di Indonesia.
\end{abstract}

Kata-kata Kunci: Arbitrase; Sengketa; Kontrak Tambang Emas.

\begin{abstract}
This article discusses the settlement of disputes in the gold mining contract through arbitration. Law Number 4 of 2009 specifies that any disputes that arise in the implementation of mining license should be resolved through arbitration in domestic courts and in accordance with the provisions of the legislation. In this paper the author argues that choosing arbitration as a dispute resolution mechanism is more proper than choosing court litigation. That is because arbitration has several advantages such as faster dispute resolution process, the "win-win" nature, as well as the guarantee of confidentiality from public scrutiny. Based on these advantages, arbitration is considered more appropriate to be applied in gold mining contract disputes in Indonesia.
\end{abstract}

Key Words: Arbitration; Dispute; Gold Mining Contract. 


\section{PENDAHULUAN}

Setiap manusia mempunyai berbagai macam kepentingan yang berupa suatu tuntutan baik perseorangan maupun kelompok yang diharapkan untuk dapat dipenuhi. Dalam upaya untuk memenuhi kepentingan tersebut manusia membutuhkan bantuan dari manusia lain. Hal ini dapat dipahami karena selain sebagai makhluk individu, maka manusia adalah makhluk sosial yang selalu membutuhkan bantuan dan kehadiran manusia lain dalam kehidupan bermasyarakat. ${ }^{1}$

Salah satu perwujudan dari adanya hubungan antar manusia dilaksanakan melalui kontrak atau perjanjian. Kontrak atau perjanjian dilaksanakan oleh manusia dalam interaksinya baik secara sadar maupun tanpa disadari. Kontrak atau perjanjian di sini memiliki pengertian suatu peristiwa di mana seorang berjanji kepada orang lain atau di mana dua orang itu saling berjanji untuk melaksanakan sesuatu hal. ${ }^{2}$ Kontrak atau perjanjian tersebut menerbitkan perikatan antara dua orang yang membuatnya.

Adapun pengertian kontrak atau perjanjian diatur dalam Pasal 1313 Kitab Undang-Undang Hukum Perdata (KUH Perdata) yang menentukan bahwa suatu kontrak atau perjanjian adalah suatu perbuatan dengan mana satu orang atau lebih mengikatkan dirinya terhadap satu orang lain atau lebih. Berdasarkan rumusan tersebut, maka suatu kontrak atau perjanjian adalah:

1. Suatu perbuatan;

2. Antara sekurang-kurangnya dua orang;

3. Perbuatan tersebut melahirkan perikatan di antara pihak-pihak yang berjanji. ${ }^{3}$

Menurut asas konsensualisme, suatu kontrak atau perjanjian lahir pada detik tercapainya kesepakatan atau persetujuan antara kedua belah pihak. Sepakat adalah suatu persesuaian paham dan kehendak antara dua pihak tersebut, apa yang dikehendaki oleh pihak yang satu adalah juga yang dikehendaki oleh pihak yang lain, meskipun tidak sejurus tetapi secara timbal balik. ${ }^{4}$

Suatu kontrak atau perjanjian harus memenuhi syarat sahnya kontrak atau perjanjian, yaitu kata sepakat, kecakapan, hal tertentu dan suatu sebab yang halal, sebagaimana ditentukan dalam Pasal 1320 KUH Perdata dan dengan dipenuhinya empat syarat sahnya perjanjian tersebut, maka suatu kontrak atau perjanjian menjadi sah dan mengikat secara hukum bagi para pihak yang membuatnya. ${ }^{5}$

Menurut Pasal 1315 KUH Perdata, pada umumnya tiada seorang pun dapat

\footnotetext{
Sudikno Mertokusumo, Mengenal Hukum, Suatu Pengantar (Liberty 1991) 1.

Subekti, Hukum Perjanjian (Intermasa 1998) 1.

Kartini Mulyadi dan Gunawan Widjaja, Perikatan Yang Lahir Dari Perjanjian (PT. Raja Grafindo Persada 2004) 7.

$4 \quad$ Subekti, Op.Cit. 26.

5 Suharnoko, Hukum Perjanjian, Teori dan Analisa Kasus (Prenada Media 2005) .
} 
mengikatkan diri atas nama sendiri atau meminta ditetapkannya suatu janji, melainkan untuk dirinya sendiri. Asas tersebut dinamakan asas kepribadian. Memang sudah semestinya, perikatan hukum yang dilahirkan oleh suatu kontrak atau perjanjian hanya mengikat orang-orang yang mengadakan kontrak atau perjanjian itu sendiri dan tidak mengikat orang-orang lain. Suatu kontrak atau perjanjian hanya meletakkan hak-hak dan kewajibankewajiban antara para pihak yang membuatnya. Orang-orang lain adalah pihak ketiga yang tidak mempunyai sangkut paut dengan kontrak atau perjanjian tersebut. ${ }^{6}$

Selanjutnya Pasal 1338 ayat (3) KUH Perdata menentukan bahwa kontrak atau perjanjian harus dilaksanakan dengan itikad baik. Rumusan tersebut memberikan arti bahwa sebagai sesuatu yang disepakati dan disetujui oleh para pihak, atau prestasi, harus dihormati sepenuhnya, sesuai dengan kehendak para pihak pada saat kontrak atau perjanjian ditutup. Namun demikian adakalanya tidaklah mudah untuk menjelaskan dan menguraikan kembali kehendak para pihak, terlebih lagi jika pihak yang terkait dengan kontrak atau perjanjian tersebut sudah tidak ada lagi, adalah suatu badan hukum yang para pengurusnya pada saat kontrak atau perjanjian dibuat tidak lagi menjabat, ataupun dalam hal terjadi pengingkaran terhadap kontrak atau perjanjian tersebut oleh salah satu pihak dalam kontrak atau perjanjian. Dalam keadaan yang demikian, maka selain dapat dibuktikan dengan bukti tertulis atau adanya keberadaan saksi yang turut menyaksikan keadaan pada saat ditutupnya kontrak atau perjanjian, maka pelaksanaan atau pemenuhan prestasi dalam perikatan sulit sekali dapat dipaksakan. ${ }^{7}$

Hal kedua yang mendasari keberadaan Pasal 1338 KUH Perdata dengan rumusan itikad baik adalah bahwa suatu kontrak atau perjanjian yang dibuat hendaknya dari sejak kontrak atau perjanjian ditutup, kontrak atau perjanjian tersebut sama sekali tidak dimaksudkan untuk merugikan kepentingan debitor maupun kreditor, maupun pihak lain atau pihak ketiga lainnya di luar kontrak atau perjanjian. Sebagaimana diketahui bahwa dalam suatu masyarakat modern, berbagai bentuk kontrak atau perjanjian merupakan suatu kebutuhan bagi mereka karena melalui kontrak atau perjanjian, baik secara lisan maupun secara tertulis, kebutuhan tiap-tiap individu manusia dalam interaksinya dengan manusia lain dapat terpenuhi.

Fokus tulisan ini adalah penyelesaian sengketa dalam kontrak tambang emas melalui arbitrase. Pengaturan kontrak dalam implementasi kerjasama tambang emas mengacu pada Undang-Undang Nomor 4 Tahun 2009 tentang Pertambangan Mineral dan Batubara (UU No. 4 Tahun 2009). Pengaturan tersebut sejalan dengan Pasal 33 ayat (3) Undang-Undang Dasar 
Negara Republik Indonesia Tahun 1945 (UUD NRI 1945) yang menentukan bahwa bahan tambang merupakan salah satu sumber daya alam yang dikuasai oleh negara dan harus dapat dimanfaatkan secara optimal untuk sebesar-besarnya kemakmuran rakyat. Oleh karena itu, sektor pertambangan merupakan salah satu sektor yang memegang peranan penting dalam menunjang pembangunan nasional. Atas dasar itu maka permasalahan yang secara spesifik ingin dibahas adalah: Pertama, pengaturan kontrak dalam implementasi kerjasama tambang emas. Kedua, hambatan yang dihadapi dalam penyelesaian konflik kontrak tambang emas. Ketiga, arbitrase sebagai mekanisme penyelesaian sengketa kontrak tambang emas.

\section{PEMBAHASAN}

\section{Pengaturan Kontrak dalam Implementasi Kerjasama Tambang Emas}

Pertambangan di Indonesia dimulai berabad-abad lalu. Namun pertambangan komersial baru dimulai pada zaman penjajahan Belanda, diawali dengan pertambangan batubara di Pengaron-Kalimantan Timur (1849) dan pertambangan timah di Pulau Bilitun (1850). Sementara pertambangan emas modern dimulai pada tahun 1899 di Bengkulu-Sumatera. Pada awal abad ke-20, pertambangan-pertambangan emas mulai dilakukan di lokasi-lokasi lainnya di Pulau Sumatera. Pada tahun 1928, Belanda mulai melakukan penambangan Bauksit di Pulau Bintan dan tahun 1935 mulai menambang nikel di Pomalaa-Sulawesi.

Setelah masa Perang Dunia II (19501966), produksi pertambangan Indonesia mengalami penurunan. Baru menjelang tahun 1967, pemerintah Indonesia merumuskan kontrak karya (KK). KK pertama diberikan kepada PT. Freeport Sulphure (sekarang PT. Freeport Indonesia). Berdasarkan jenis mineralnya, pertambangan di Indonesia terbagi menjadi tiga kategori, yaitu:

a. Pertambangan Golongan A, meliputi mineral-mineral strategis seperti: minyak, gas alam, bitumen, aspal, natural wax, antrasit, batu bara, uranium dan bahan radioaktif lainnya, nikel dan cobalt.

b. Pertambangan Golongan B, meliputi mineral-mineral vital, seperti: emas, perak, intan, tembaga, bauksit, timbal, seng dan besi.

c. Pertambangan Golongan C, umumnya mineral-mineral yang dianggap memiliki tingkat kepentingan lebih rendah daripada kedua golongan pertambangan lainnya. Antara lain meliputi berbagai jenis batu, limestone, dan lain-lain.

Eksploitasi mineral golongan A dilakukan Perusahaan Negara, sedang perusahaan asing hanya dapat terlibat sebagai partner. Sementara eksploitasi mineral golongan B dapat dilakukan baik oleh perusahaan asing maupun Indonesia. Eksploitasi mineral golongan C dapat dilakukan oleh perusahaan Indonesia maupun perusahaan perorangan. 
Adapun pelaku pertambangan di Indonesia dapat dikategorikan menjadi tiga, yaitu Negara, Kontraktor dan Pemegang KP (Kuasa Pertambangan). Selanjutnya beberapa isu-isu penting permasalahan pada pertambangan, adalah ketidakpastian kebijakan, penambangan liar, konflik dengan masyarakat lokal, konflik sektor pertambangan dengan sektor lainnya.

Bahan tambang merupakan salah satu sumber daya alam yang dikuasai oleh negara dan harus dapat dimanfaatkan secara optimal untuk sebesar-besarnya kemakmuran rakyat (amanat UUD NRI 1945 Pasal 33 ayat 3). Oleh karena itu, sektor pertambangan merupakan salah satu sektor yang memegang peranan penting dalam menunjang pembangunan nasional. Indonesia mempunyai potensi berbagai jenis bahan tambang, baik logam, non logam, batuan bahan konstruksi dan industri, batu bara, panas bumi maupun minyak dan gas bumi yang cukup melimpah. Pendayagunaan secara bijak segala jenis bahan tambang tersebut dapat meningkatkan pendapatan dan perekonomian nasional ataupun daerah.

Setiap kegiatan penambangan hampir dipastikan akan menimbulkan dampak terhadap lingkungan, baik bersifat positif maupun bersifat negatif. Dampak positif kegiatan penambangan antara lain meningkatkan kesempatan kerja, meningkatkan roda perekonomian sektor dan sub sektor lain di sekitarnya, dan menambah penghasilan negara maupun daerah dalam bentuk pajak, retribusi ataupun royalti. Namun demikian, kegiatan penambangan yang tidak berwawasan atau tidak mempertimbangkan keseimbangan dan daya dukung lingkungan serta tidak dikelola dengan baik dapat menimbulkan dampak negatif terhadap lingkungan. Dampak negatif tersebut antara lain terjadinya gerakan tanah yang dapat menelan korban baik harta benda maupun nyawa, hilangnya daerah resapan air di daerah perbukitan, rusaknya bentang alam, pelumpuran ke dalam sungai yang dampaknya bias sampai ke hilir, meningkatkan intensitas erosi di daerah perbukitan, jalan-jalan yang dilalui kendaraan pengangkut bahan tambang menjadi rusak, mengganggu kondisi air tanah, dan terjadinya kubangan-kubangan besar yang terisi air, terutama bila penggalian di daerah pedataran, serta mempengaruhi kehidupan sosial penduduk di sekitar lokasi penambangan. Oleh karena itu, untuk menghindari berbagai dampak negatif tersebut, maka pengelolaan pertambangan yang berwawasan lingkungan mutlak harus dilakukan.

Kegiatan pertambangan dapat diartikan sebagai suatu tahapan kegiatan yang diawali dengan penyelidikan umum, eksplorasi, studi kelayakan, konstruksi, penambangan (termasuk bila ada pengolahan dan pemurnian), pengangkutan/penjualan dan diakhiri dengan rehabilitasi lahan pasca tambang. Pengelolaan pertambangan adalah suatu upaya yang dilakukan baik secara teknis maupun non teknis agar kegiatan pertambangan 
tersebut tidak menimbulkan permasalahan, baik terhadap kegiatan pertambangan itu sendiri maupun terhadap lingkungan. Pengelolaan pertambangan sering hanya dilakukan pada saat penambangan saja. Hal ini dapat dimengerti, karena pada tahap inilah dinilai paling banyak atau sering menimbulkan permasalahan apabila tidak dikelola dengan baik dan benar. Persepsi yang demikian kurang tepat. Pengelolaan pertambangan sebaiknya dilakukan sejak awal hingga akhir tahapan seperti tersebut di atas. Bahkan untuk mengantisipasi terjadinya permasalahan, maka sebelum suatu deposit bahan tambang ditambang, perlu dilakukan kajian terlebih dahulu apakah deposit tersebut layak untuk ditambang ditinjau dari berbagai aspek. Dengan demikian pengelolaan pertambangan secara garis besar perlu dilakukan pada 3 (tiga) jenis tahapan kegiatan, yaitu kegiatan awal berupa penentuan kelayakan penambangan, kegiatan kedua pada saat penambangan (eksploitasi), dan kegiatan ketiga/ terakhir pada saat reklamasi lahan pasca penambangan.

Sudah lebih dari lima tahun UU No. 4 Tahun 2009 diundangkan, undangundang ini masih menyisakan banyak tanda tanya. Salah satunya di bidang penyelesaian sengketa pertambangan. Satu-satunya pasal yang mengatur mengenai penyelesaian sengketa adalah Pasal 154 UU No. 4 Tahun 2009 yang berbunyi: "Setiap sengketa yang muncul dalam pelaksanaan IUP, IPR, atau IUPK diselesaikan melalui pengadilan dan arbitrase dalam negeri sesuai dengan ketentuan peraturan perundangundangan." Pada Penjelasan atas Pasal tersebut dinyatakan: Cukup jelas. Bermasalahkah aturan tersebut, yang memuat ketentuan mengenai penyelesaian sengketa di dalam negeri?

Dalam lapangan hukum bisnis, pada dasarnya ada dua cara penyelesaian sengketa, yaitu di dalam dan di luar pengadilan. Di dalam pengadilan, seperti dalam perkara perdata atau tata usaha negara pada umumnya, hakim berfungsi sebagai penengah di antara penggugat dan tergugat. Lain halnya jika diselesaikan di luar pengadilan, banyak yang dapat dilakukan, beberapa di antaranya negosiasi, mediasi, konsiliasi, dan arbitrase. Keempatnya lebih jauh diatur oleh Undang-Undang Nomor 30 Tahun 1999 tentang Arbitrase dan Alternatif Penyelesaian Sengketa (UU No. 30 Tahun 1999).

Tidak menjadi persoalan seandainya pengadilan merupakan satu-satunya jalur untuk penyelesaian sengketa, karena - dengan mekanisme teranyar dari UU No. 4 tahun 2009 - sengketa yang mungkin terjadi adalah soal keputusan mengenai izin pertambangan (IUP, IPR, dan IUPK) yang tak lain adalah ranah dari Pengadilan Tata Usaha Negara (PTUN). Sudah barang tentu perkara terkait tata usaha negara ini harus diadili di dalam negeri. Seandainya pun bukan kompetensi dari PTUN, maka yang paling mungkin terjadi perkara pertambangan akan masuk ke peradilan perdata yang tentu saja dilaksanakan di dalam negeri. 
Namun, hampir tidak mungkin semua perkara diselesaikan melalui jalur pengadilan, terlebih lagi pertambangan adalah salah satu sektor bisnis yang menarik perhatian. Sengketa pertambangan acap kali diselesaikan melalui penyelesaian sengketa di luar pengadilan khususnya arbitrase. Memang, sekali lagi, dengan diterapkannya rezim perizinan dalam usaha pertambangan, sengketa tata usaha negara-lah yang mungkin akan sering terjadi, misalnya dalam hal pencabutan izin. Tidak semua sengketa dalam pelaksanaan IUP, IPR, dan IUPK merupakan lingkup kompetensi absolut dari PTUN. Dengan begitu, penyelesaian sengketa di luar pengadilan menjadi pilihan. Dari berbagai pilihan penyelesaian sengketa, arbitrase kerap mengemuka menjadi pilihan para pihak.

Arbitrase, dalam dunia bisnis sering menjadi pilihan dalam menyelesaian sengketa. Dalam beberapa perkara, khususnya yang high profile, kerahasiaan (confidentiality) sering menjadi persoalan. Arbitrase menjadi pilihan karena baik jalannya pemeriksaan perkara maupun putusannya bersifat konfidensial. Dalam dunia bisnis kepastian adalah segalagalanya. Arbitrase juga dianggap lebih memberi kepastian karena sifat putusannya yang final dan mengikat (final and binding), tanpa ada proses banding, kasasi dan PK, dan mengikat para pihak yang bersengketa. Pada intinya, arbitrase, ke depannya, kemungkinan besar akan terus menjadi pilihan banyak pelaku usaha, salah satunya di bidang pertambangan.
Melihat prospek arbitrase yang demikian, bermasalahkah Pasal 154 UU No. 4 Tahun 2009? Bisa jadi. Salah satu poin penting dari arbitrase adalah kebebasan berkontrak. Pada dasarnya arbitrase adalah kesepakatan di antara para pihak. Bagaimana seandainya para pihak dalam perjanjian arbitrase menentukan bahwa tempat arbitrase di luar negeri? Kemungkinan ini sangat besar terjadi mengingat banyak investor dalam industri pertambangan adalah anak perusahaan dari perusahaan asing.

Industri pertambangan adalah bagian dari sistem besar penanaman modal asing di Indonesia. Dengan begitu, sengketa dalam bisnis pertambangan mungkin sekali juga terkait dengan sengketa di bidang investasi. Indonesia telah menjadi pihak dalam Convention on the Settlement of Investment Disputes between States and National of Other States. Dalam konvensi tersebut, sengketa investasi dilaksanakan di ICSID (International Center of the Settlement of Investment Disputes). Bagaimana jika para pihak dalam sengketa pelaksanaan IUP, IPR, dan IUPK memutuskan untuk menyelesaikan sengketa di ICSID, tetapi Pasal 154 UU No. 4 Tahun 2009 menyatakan arbitrase harus dilaksanakan di dalam negeri? Dengan begitu muncul pertanyaan: Sejauh apakah Pasal 154 UU Nomor 4 Tahun 2009 tersebut berlaku? Imperatif atau fakultatif? 
Substansi pasal tersebut mungkin akan mengundang perdebatan panjang. Untuk lebih efisien, bukankah lebih baik jika pasal itu tidak ada, seperti pada dua undang-undang pertambangan sebelumnya. Barangkali dua undangundang sebelum UU No. 4 Tahun 2009 tidak mutlak menerapkan rezim perizinan. Akan tetapi, bukankah tanpa Pasal 154 tersebut - jika terjadi sengketa soal keputusan pejabat tata usaha negara, gubernur atau bupati/walikota mengenai izin pertambangan penyelesaian sengketa akan tetap menggunakan forum PTUN. Kiranya, jika pun tidak dicabut, perlu dibuat aturan pelaksanaan dari Pasal 154 UU No. 4 Tahun 2009 ini karena akan menimbulkan ketidakjelasan dalam penyelesaian sengketa pertambangan di Indonesia.

\section{Hambatan yang Dihadapi dalam Penyelesaian Konflik Kontrak Tambang Emas}

Pasal 33 ayat (3) UUD NRI 1945 menegaskan bahwa bumi, air, dan kekayaan alam yang terkandung di dalamnya dikuasai oleh negara dan dipergunakan untuk sebesar-besar kemakmuran rakyat. Mengingat mineral dan batubara sebagai kekayaan alam yang terkandung di dalam bumi merupakan sumber daya alam yang tak terbarukan, pengelolaannya perlu dilakukan seoptimal mungkin, efisien, transparan, berkelanjutan dan berwawasan lingkungan, serta berkeadilan agar memperoleh manfaat sebesar-besar bagi kemakmuran rakyat secara berkelanjutan.
Guna memenuhi ketentuan Pasal 33 ayat (3) UUD NRI 1945 tersebut, telah diterbitkan Undang-Undang Nomor 11 Tahun 1967 tentang KetentuanKetentuan Pokok Pertambangan (UU No. 11 Tahun 1967). Undang-undang tersebut selama lebih kurang empat dasawarsa sejak diberlakukannya telah dapat memberikan sumbangan yang penting bagi pembangunan nasional sebelum kemudian digantikan oleh UU No. 4 Tahun 2009.

Dalam perkembangan lebih lanjut, undang-undang tersebut yang materi muatannya bersifat sentralistik sudah tidak sesuai dengan perkembangan situasi sekarang dan tantangan di masa depan. Di samping itu, pembangunan pertambangan harus menyesuaikan diri dengan perubahan lingkungan strategis, baik bersifat nasional maupun internasional. Tantangan utama yang dihadapi oleh pertambangan mineral dan batubara adalah pengaruh globalisasi yang mendorong demokratisasi, otonomi daerah, hak asasi manusia, lingkungan hidup, perkembangan teknologi dan informasi, hak atas kekayaan intelektual serta tuntutan peningkatan peran swasta dan masyarakat.

Untuk menghadapi tantangan lingkungan strategis dan menjawab sejumlah permasalahan tersebut, perlu disusun peraturan perundangundangan baru di bidang pertambangan mineral dan batubara yang dapat memberikan landasan hukum bagi langkah-langkah pembaruan dan penataan kembali kegiatan pengelolaan 
dan pengusahaan pertambangan mineral dan batubara.

UU No. 4 Tahun 2009 mengandung pokok-pokok pikiran sebagai berikut:

a. Mineral dan batubara sebagai sumber daya yang tak terbarukan dikuasai oleh negara dan pengembangan serta pendayagunaannya dilaksanakan oleh Pemerintah dan pemerintah daerah bersama dengan pelaku usaha.

b. Pemerintah selanjutnya memberikan kesempatan kepada badan usaha yang berbadan hukum Indonesia, koperasi, perseorangan, maupun masyarakat setempat untuk melakukan pengusahaan mineral dari batubara berdasarkan izin, yang sejalan dengan otonomi daerah, diberikan oleh Pemerintah dan/atau pemerintah daerah sesuai dengan kewenangannya masing-masing.

c. Dalam rangka penyelenggaraan desentralisasi dan otonomi daerah, pengelolaan pertambangan mineral dan batubara dilaksanakan berdasarkan prinsip eksternalitas, akuntabilitas, dan efisiensi yang melibatkan Pemerintah dan pemerintah daerah.

d. Usaha pertambangan harus memberi manfaat ekonomi dan sosial yang sebesar-besar bagi kesejahteraan rakyat Indonesia.

e. Usaha pertambangan harus dapat mempercepat pengembangan wilayah dan mendorong kegiatan ekonomi masyarakat/pengusaha kecil dan menengah serta mendorong tumbuhnya industri penunjang pertambangan.

f. Dalam rangka terciptanya pembangunan berkelanjutan, kegiatan usaha pertambangan harus dilaksanakan dengan memperhatikan prinsip lingkungan hidup, transparansi, dan partisipasi masyarakat.

Kenyataan tidak berkorelasinya antara berlimpahnya kekayaan Indonesia dengan kesejahteraan rakyatnya merupakan anomali. Dari anomali itu, sampai pada sebuah kesimpulan, yakni pasti ada sesuatu yang salah dalam pengelolaan kekayaan bahan galian di Indonesia. Namun di mana letak kesalahan itu terjadi? Hal ini memerlukan kejujuran dan kearifan untuk menjawabnya. Melalui, kejujuran dan kearifan diyakini dapat melahirkan sebuah jawaban solutif, guna menghindari kesalahan itu tidak terulang kembali.

Terdapat beberapa kesalahan yang telah dilakukan bangsa ini dalam melakukan pengelolaan kekayaan sumber daya bahan galian. Kesalahan itu, apabila dituntut bersifat kompleks dan sistematis. Kompleksitas dan sistematisnya kesalahan dimaksud, karena berawal dari kebijakan yang dibuat dalam melaksanakan pengelolaan dan pengusahaan bahan galian selama ini. Secara garis besar, kesalahan tersebut dapat dikelompokkan menjadi 3 kelompok besar, yaitu:

a. Kesalahan pemaknaan atas esensi Pasal 33 ayat (3) UUD NRI 1945 
tentang hak menguasai negara atas bahan galian;

b. Kelemahan landasan yuridis formal tentang pengelolaan dan pengusahaan bahan galian. Kelemahan ini berkaitan erat dengan kesalahan pemaknaan atas esensi Pasal 33 ayat (3) UUD NRI 1945 di atas. Sebagaimana diketahui, landasan hukum kegiatan usaha pertambangan yang berlaku sebelumnya yaitu UU No. 11 Tahun 1967, tidak mempunyai keberpihakan sama sekali terhadap rakyat.

c. Keserakahan pelaku kegiatan usaha pertambangan dan oknum pemerintah. Ini terjadi dan berlangsung berpuluh-puluh tahun lamanya, didorong dan disebabkan oleh doa faktor di atas. Para oknum pelaku usaha dan pemerintah dengan jeli memanfaatkan kesalahan pemaknaan dan kelemahan peraturan perundangundangan untuk mengeruk kekayaan sumber daya bahan galian, hanya demi kepentingannya sendiri.

Kesalahan pemaknaan atas esensi Pasal 33 ayat (3) UUD NRI 1945, kelemahan pengaturan pertambangan dan keserakahan yang ditengarai dilakukan pelaku usaha pertambangan dan oknum pemerintah, berpadu menjadi satu kesatuan utuh, sehingga membuat persoalan pengelolaan dan pengusahaan bahan galian tidak sebatas kecilnya hasil yang diterima negara dan bangsa ini, tetapi juga telah mendorong berbagai kenyataan pahit, terkorbankannya kepentingan rakyat setempat khususnya dan negara pada umumnya.

Di lain pihak, ternyata pemerintah dalam praktiknya tidak mempunyai daya paksa terhadap pelaku kegiatan usaha pertambangan yang nakal, malahan ada kecenderungan selalu mengalah pada kepentingan investor. Kecenderungan tersebut, dapat dilihat dari fakta-fakta sebagai berikut:

a. Lemahnya posisi pemerintah dalam melakukan negosiasi pengelolaan dan pengusahaan bahan galian, hal tersebut berimplikasi pada kecilnya bagian yang dapat diterima negara atas hasil bahan galian yang dieksploitasi;

b. Munculnya beberapa paket kebijakan yang memanjakan investor pertambangan, seperti insentif atau keringanan pajak, bebas bea masuk barang dan peralatan produksi, dan lain-lain;

c. Kebebasan investor untuk melakukan penjualan produk bahan galian yang dihasilkan dalam bentuk bijih (batu), bukan produk yang telah mengalami pengolahan dan pemurnian;

d. Tidak adanya kebijakan yang berpihak untuk kepentingan nasional secara nyata, misalnya kebijakan yang melarang ekspor bahan galian dalam bentuk bijih.

Kesalahan, kelemahan, dan faktafakta di atas, merupakan penyebab utama tidak maksimalnya manfaat yang dapat diambil atas bahan galian yang 
telah berhasil dieksploitasi. Sehingga dari kesalahan, dan kelemahan itu pulalah, sangat memungkinkan terjadinya berbagai bentuk manipulasi data yang berujung pada kerugian negara. Bentuk-bentuk manipulasi tersebut, di antaranya:

a. Manipulasi jumlah cadangan dan produksi tambang, manipulasi dalam konteks ini sesungguhnya sangat konvensional, tetapi karena masuknya berbagai kepentingan, maka manipulasi itu terus terjadi.

b. Manipulasi kadar bahan galian, karena dengan cara menurunkan kadar bahan galian, akan berpengaruh pada harga jual, dan harga jual mempengaruhi formulasi nilai pajak dan penerimaan negara bukan pajak bahan galian yang harus dibayar kepada negara.

Perjalanan dan penantian panjang atas kondisi pengelolaan dan pengusahaan bahan galian yang terjadi selama ini, untuk sementara cukup terobati, sejalan dengan telah lahirnya UU No. 4 Tahun 2009 tentang Pertambangan Mineral dan Batubara. Secara substansi Undang-undang ini cukup mengakomodasi gejolak dan kegelisahan sebagian warga bangsa ini, tinggal menunggu pada tataran implementasinya. Bentuk-bentuk akomodasi dimaksud adalah tercantumnya beberapa aturan yang secara yuridis mempunyai keberpihakan, baik terhadap kepentingan rakyat setempat maupun kepentingan nasional, yaitu: a. Diakomodasinya pertambangan rakyat secara proporsional;

b. Adanya fungsi pengendalian negara/ pemerintah dalam pengelolaan dan pengusahaan bahan galian;

c. Pendelegasian pengelolaan dan pengusahaan bahan galian dilakukan secara fair, yaitu melalui mekanisme lelang;

d. Kewenangan masing-masing wilayah administratif atas pengelolaan bahan galian diatur dengan jelas.

Saat ini yang menjadi sorotan internasional terhadap Indonesia adalah masalah pertambangan dan kerusakan yang ditimbulkannya pada kehidupan manusia dan lingkungan sekitar. Perhatian internasional itu tentu saja beralasan mengingat praktik hukum di Indonesia masih menunjukkan adanya kelemahan dalam pemberian perizinan, pengelolaan, pengawasan dan penegakan hukum pertambangan terhadap berbagai aspek pelanggaran hukum yang ditimbulkannya. Padahal persoalan mengenai pemanfaatan, pengelolaan serta pelestarian sumber daya alam telah menjadi isu penting internasional dengan disepakatinya berbagai deklarasi, antara lain Deklarasi Stocholm, Deklarasi Nairobi, Deklarasi Johannesburg, Deklarasi Rio De Jeneiro, termasuk The Earth Charter.

Sorotan internasional terhadap praktik eksplorasi pertambangan di Indonesia sangat beralasan, mengingat kerusakan yang dimunculkan terhadap kelestarian alam dari eksplorasi pertambangan sangat berdampak luas bagi kelangsungan kehidupan manusia. Pertambangan sebagai suatu kegiatan 
usaha yang sangat tua di dunia banyak meninggalkan dampak bagi kehidupan manusia. Sedangkan di Indonesia sendiri pertambangan secara tradisional sudah ada sejak zaman sebelum penjajahan Belanda. Baru setelah masuknya penjajah di Indonesia pertambangan dilakukan secara modern. Demikian pula masa sekarang ini pertambangan mineral dan batu bara dilakukan dengan terbuka. Artinya tidak dilakukan secara tertutup, yaitu dengan menggunakan terowongan. Melainkan dilakukan secara terbuka dengan cara menggali permukaan tanah.

Ketidakpastian kebijakan mengakibatkan tidak adanya jaminan hukum dan kebijakan yang dapat menarik para investor asing untuk menanamkan modal di Indonesia. Menurut Pricewaterwaterhouse Coopers (PwC), dalam laporan Indonesian Mining Industry Survey 2002, kekurangpercayaan investor terlihat dari penurunan eksplorasi dan kelayakan, serta pengeluaran untuk pengembangan dan aktiva. Tahun 2001, pengeluaran menurun $42 \%$ dibanding tahun 2000 , sedangkan pengeluaran untuk aktiva dan pengembangan tahun 2001 hanya 15\% dibanding rata-rata pengeluaran periode 1996-1999. Pengeluaran untuk eksplorasi dan kelayakan tahun 2001 menurun dari rata-rata pengeluaran tahun 1996-1999, sebesar US\$ 434,3 juta menjadi US\$ 37,9.

Penambangan liar disebabkan oleh lemahnya penerapan hukum dan kurang baiknya sistem perekonomian, sehingga mendorong masyarakat mencari mata pencaharian yang cepat menghasilkan. Salah satu bentuk penambangan liar yang sering dibicarakan adalah PETI (Pertambangan Emas Tanpa Ijin). Pertambangan seperti ini banyak ditemui di pedalaman Kalimantan. Di sana masyarakat setempat mendulang emas di sepanjang tepian sungai dengan peralatan tradisional. Salah satu sungai yang ramai oleh pertambangan emas masyarakat adalah Sungai Kahayan. Kegiatan PETI berdampak cukup serius, seperti pendangkalan sungai, terganggunya alur pelayaran kapal oleh pasir gusung, pencemaran air sungai oleh merkuri, dan berkurangnya sumber protein bagi masyarakat (ikan).

Pada saat produksi, terdapat beberapa potensi konflik, seperti kesenjangan sosial ekonomi, perbedaan sosial budaya, serta munculnya rantai sosial akibat munculnya kluster kegiatan ekonomi beresiko sosial tinggi (premanisme, lokalisasi, dll). Sementara, pada saat pasca pertambangan, terdapat beberapa potensi konflik, seperti pengangguran, klaim terhadap lahan pasca pertambangan, munculnya pertambangan rakyat, dan sisa aktivitas sosial.

Dalam hal konflik sektor pertambangan dengan sektor lainnya misalnya konflik dalam penataan dan pemanfaatan ruang, pelestarian lingkungan, serta konflik pertambangan dengan sektor kehutanan dalam penggunaan lahan hutan lindung untuk kegiatan pertambangan. Penyebab 
konflik sektor pertambangan dengan sektor lain, antara karena:

a. Sulitnya Mengakomodasi Kegiatan Pertambangan ke dalam Penataan Ruang

Hal ini dilatarbelakangi oleh adanya terminologi land use dan land cover dalam penataan ruang. Land use (penggunaan lahan) merupakan alokasi lahan berdasarkan fungsinya, seperti permukiman, pertanian, perkebunan, perdagangan, dan sebagainya. Sementara land cover merupakan alokasi lahan berdasarkan tutupan lahannya, seperti sawah, semak, lahan terbangun, lahan terbuka, dan sebagainya. Pertambangan tidak termasuk ke dalam keduanya, karena kegiatan sektor pertambangan baru dapat berlangsung jika ditemukan kandungan potensi mineral di permukaan tanah pada kedalaman tertentu. Meskipun diketahui memiliki kandungan potensi mineral, belum tentu dapat dieksploitasi seluruhnya, karena terkait dengan besaran dan nilai ekonomis kandungan mineral tersebut. Proses penetapan kawasan pertambangan yang membutuhkan lahan di atas permukaan tanah membutuhkan waktu lebih lama dibandingkan dengan proses penataan ruang itu sendiri.

b. Sering Dituduh sebagai 'Biang Keladi’ Kerusakan Lingkungan

Kerusakan akibat pertambangan dapat terjadi selama kegiatan pertambangan maupun pasca pertambangan. Dampak lingkungan sangat terkait dengan teknologi dan teknik pertambangan yang digunakan. Sementara teknologi dan teknik pertambangan tergantung pada jenis mineral yang ditambang dan kedalaman bahan tambang, misalnya penambangan batubara dilakukan dengan sistem tambang terbuka, sistem dumping (suatu cara penambangan batubara dengan mengupas permukaan tanah). Beberapa permasalahan lingkungan yang terjadi akibat kegiatan pertambangan, antara lain masalah tailing, hilangnya biodiversity akibat pembukaan lahan bagi kegiatan pertambangan, adanya air asam tambang.

c. Tumpang Tindih Pemanfaatan Ruang dengan Lahan Kehutanan

Hutan merupakan ekosistem alami tempat senyawa-senyawa organik mengalami pembusukan dan penimbunan secara alami. Setelah cukup lama, materi-materi organik tersebut membusuk, akhirnya tertimbun karena terdesak lapisan materi organik baru. Itu sebabnya hutan merupakan tempat yang sangat mungkin mengandung banyak bahan mineral organik, yang potensial untuk dijadikan sebagai bahan tambang.

Saat ini pertambangan sering dilakukan di daerah terpencil, bahkan di kawasan hutan lindung. Menurut TEMPO Interaktif (4 Maret 2003), terdapat 22 perusahaan tambang beroperasi di kawasan hutan lindung dan sempat ditutup. Total investasi 22 perusahaan tersebut mencapai US\$ 12,2 miliar (Rp 160 triliun). Kegiatan pertambangan dinilai akan merusak 
ekosistem hutan lindung, yang berfungsi sebagai kawasan konservasi alam.

Dalam suatu kegiatan penambangan biasanya terdiri dari beberapa tahapan, yaitu tahap persiapan, tahap eksploitasi dan terakhir, yang merupakan bagian tak terpisahkan, adalah tahap reklamasi/rehabilitasi lahan pasca penambangan.

\section{a. Tahap Persiapan}

Tahap persiapan biasanya didahului dengan kegiatan pengangkutan berbagai jenis peralatan tambang, termasuk bahan-bahan bangunan untuk pembuatan perkantoran, gudang, perumahan (jika ada) dan fasilitasfasilitas tambang yang lain, pembukaan lahan (land-clearing), dan selanjutnya adalah pembuatan/pembukaan jalan tambang. Dalam hal pengangkutan peralatan tambang dan bahan-bahan bangunan, yang perlu diperhatikan adalah jalan yang akan dilalui. Perlu diperhitungkan berapa meter lebar jalan, jalan apakah melewati jembatan (bagaimana kondisinya), apakah melewati pemukiman penduduk, berapa frekuensi lalu-lalang dan jenis maupun tonase truk pengangkut, dan sebagainya. Hal-hal tersebut perlu diperhitungkan secara matang agar tidak terjadi dampak negatif terhadap lingkungan di sepanjang jalan yang akan dilalui, baik terhadap manusia maupun fisik alam itu sendiri. Beberapa contoh dampak negatif yang dapat ditimbulkan oleh adanya kegiatan pengangkutan ini apabila tidak dikelola dengan baik, antara lain adalah jalan menjadi rusak (banyak lubang, becek di musim hujan), kecelakaan lalu-lintas (karena jalan terlalu sempit, atau kondisi jembatan kurang memenuhi syarat), debu bertebaran yang dapat menimbulkan gangguan kesehatan (karena jalan berupa tanah dan dilalui kendaraan pada musim kemarau), dan ganggunan kebisingan.

Pada kegiatan pembukaan lahan perlu diperhatikan kemiringan dan kestabilan lereng, bahaya erosi dan sedimentasi (karena penebangan pepohonan, terutama saat musim hujan), serta hindari penempatan hasil pembukaan lahan terhadap sistem drainase alam yang ada. Demikian pula pada saat pembuatan jalan tambang.

Lokasi pembuatan fasilitas tambang, seperti perkantoran, gudang, dan perumahan perlu memperhatikan kondisi tanah/batuan dan kemiringan lerengnya. Sedapat mungkin hindari lokasi yang berlereng terjal dan kemungkinan rawan longsor. Jika diperlukan pembuatan kolam pengendapan, letakkan pada lokasi yang sifat batuannya kedap air, misalnya batu lempung, dan tidak pada batuan yang banyak kekar-kekarnya. Hal ini untuk menghindari terjadinya kebocoran. Bila kondisi batuan tidak memungkinkan, maka kolam pengendapan bisa dibuat dari beton, walaupun memerlukan tambahan biaya.

\section{b. Tahap Eksploitasi}

Kegiatan yang dilakukan pada tahap ini utamanya berupa penambangan/ penggalian bahan tambang dengan jenis dan keterdapatan bahan tambang yang 
berbeda-beda. Dengan demikian teknik/ tata cara penambangannya berbedabeda pula. Bahan tambang yang terdapat di daerah perbukitan, walaupun jenisnya sama, misalnya pasir, teknik penambangannya akan berbeda dengan deposit pasir yang terdapat di daerah pedataran, apalagi yang terdapat di dalam alur sungai. Tulisan ini tidak akan membahas berbagai teknik penambangan tersebut, tetapi akan dibahas secara umum tentang hal-hal apa saja yang perlu diperhatikan pada tahap eksploitasi dalam kaitannya dengan pengelolaan pertambangan yang berwawasan lingkungan. Hal-hal yang perlu diperhatikan antara lain sebagai berikut:

1) Jenis, sebaran dan susunan perlapisan batuan yang terdapat di sekitar deposit bahan tambang, termasuk ketebalan lapisan tanah penutup.

2) Sifat fisik dan keteknikan tanah/ batuan.

3) Kondisi hidrogeologi (kedalaman muka air tanah dangkal dan/dalam, pola aliran air tanah, sifat fisika dan kimia air tanah dan air permukaan, letak mata air dan besaran debitnya, letak dan pola aliran sungai berikut peruntukannya, sistem drainase alam).

4) Topografi/kemiringan lereng.

5) Kebencanaan geologi (kerawanan gerakan tanah, bahaya letusan gunung api, banjir, kegempaan).

6) Kandungan unsus-unsur mineral yang terdapat dalam batuan yang terdapat di sekitar deposit bahan tambang, misalnya pirit
Dengan mengetahui dan kemudian memperhitungkan seluruh data-data tersebut, maka dapat ditentukan teknik penambangan yang sesuai, sehingga dampak negatif terhadap lingkungan akibat kegiatan penambangan dapat dihindari atau ditekan sekecil mungkin.

\section{c. Tahap Reklamasi}

Kegiatan reklamasi tidak harus menunggu sampai seluruh kegiatan penambangan berakhir, terutama pada lahan penambangan yang luas. Reklamasi sebaiknya dilakukan secepat mungkin pada lahan bekas penambangan yang telah selesai dieksploitasi, walaupun kegiatan penambangan tersebut secara keseluruhan belum selesai karena masih terdapat deposit bahan tambang yang belum ditambang. Sasaran akhir dari reklamasi adalah untuk memperbaiki lahan bekas tambang agar kondisinya aman, stabil dan tidak mudah tererosi sehingga dapat dimanfaatkan kembali. Hal-hal yang perlu diperhatikan dalam pengelolaan lingkungan pada tahap reklamasi adalah sebagai berikut:

1) Rencana reklamasi sebaiknya dipersiapkan sebelum pelaksanaan penambangan

2) Luas areal yang direklamasi sama dengan luas areal penambangan

3) Memindahkan dan menempatkan tanah pucuk pada tempat tertentu dan mengatur sedemikian rupa untuk keperluan revegetasi

4) Mengembalikan/memperbaiki pola drainase alam yang rusak

5) Menghilangkan/memperkecil kandungan (kadar) bahan beracun 
(jika ada) sampai ke tingkat yang aman sebelum dibuang ke suatu tempat pembuangan

6) Mengembalikan lahan seperti semula atau sesuai dengan tujuan penggunaan

7) Memperkecil erosi selama dan setelah proses reklamasi

8) Memindahkan seluruh peralatan yang sudah tidak digunakan lagi ke tempat yang dianggap aman

9) Permukaan tanah yang padat harus digemburkan, atau ditanami dengan tanaman pionir yang akarnya mampu menembus tanah yang keras

10) Jenis tanaman yang akan dipergunakan untuk revegetasi harus sesuai dengan rencana rehabilitasi (dapat berkonsultasi dahulu dengan dinas terkait)

11) Mencegah masuknya hama dan gulma yang berbahaya

12) Memantau dan mengelola areal reklamasi sesuai dengan kondisi yang diharapkan.

Dalam beberapa kasus, lahan bekas penambangan tidak harus seluruhnya direvegetasi, namun dapat dimanfaatkan untuk tujuan lain, seperti misalnya menjadi kolam persediaan air, padang golf, perumahan, dan sebagainya apabila dinilai lebih bermanfaat atau sesuai dengan rencana tata ruang. Oleh karena itu, sebelum merencanakan reklamasi, sebaiknya berkonsultasi dahulu dengan pemerintah daerah setempat, pemilik lahan atau instansi terkait lainnya.

\section{Arbitrase sebagai Pilihan untuk Penyelesaian Sengketa}

Penyelesaian sengketa dapat dilakukan melalui 2 (dua) proses. Proses penyelesaian sengketa tertua melalui proses litigasi di dalam pengadilan, kemudian berkembang proses penyelesaian sengketa melalui kerjasama (kooperatif) di luar pengadilan. Proses litigasi menghasilkan kesepakatan yang bersifat adversarial yang belum mampu merangkul kepentingan bersama, cenderung menimbulkan masalah baru, lambat dalam penyelesaiannya, membutuhkan biaya yang mahal, tidak responsif, dan menimbulkan permusuhan di antara pihak yang bersengketa. Sebaliknya melalui proses di luar pengadilan menghasilkan kesepakatan yang bersifat "win-win solution", dijamin kerahasiaan sengketa para pihak, dihindari kelambatan yang diakibatkan karena hal prosedural dan administratif, menyelesaikan masalah secara komprehensif dalam kebersamaan, dan tetap menjaga hubungan baik. Satusatunya kelebihan proses non litigasi ini sifat kerahasiaannya, karena proses persidangan dan bahkan hasil keputusannya pun tidak dipublikasikan.

Penyelesaian sengketa di luar pengadilan ini umumnya dinamakan dengan Alternatif Penyelesaian Sengketa (APS) atau Alternative Dispute Resolution (ADR). Ada yang mengatakan kalau Alternative Dispute Resolution (ADR) ini merupakan siklus gelombang ketiga penyelesaian sengketa bisnis. Penyelesaian sengketa bisnis pada era 
globalisasi dengan ciri "moving quickly", menuntut cara-cara yang "informal procedure and be put in motion quickly". ${ }^{8}$

Penyelesaian sengketa alternatif, yaitu penyelesaian sengketa di luar pengadilan, telah berkembang sejak lama di timur dan kemudian mendapat sambutan yang sama di barat, walaupun dengan alasan yang berlainan. Penyelesaian sengketa alternatif di timur didasarkan pada alasan untuk menjaga harmoni, di mana setiap sengketa diselesaikan secara kekeluargaan. Pengadilan bukan tempat yang tepat untuk orang bisnis menyelesaikan sengketa mereka yang selalu menjaga hubungan baik. Pengadilan adalah tempat orang-orang nakal yang melanggar ketertiban. Alasan budaya menyebabkan negosiasi, mediasi, konsiliasi dan arbitrase berkembang di timur, terutama di antara bangsabangsa yang mempunyai akar kepada ajaran Confucius. Penyelesaian sengketa alternatif yang berkembang di barat, terutama karena alasan efisiensi, untuk menghemat waktu dan biaya. Proses pengadilan yang panjang, acapkali melelahkan dari Pengadilan Tingkat Pertama sampai Mahkamah Agung dan memakan biaya yang besar.

Di samping itu sedikitnya ada tiga alasan lain yang mendasar mengapa kaum bisnis lebih menyukai penyelesaian sengketa yang timbul di antara mereka diselesaikan di luar pengadilan, yaitu: Pertama, penyelesaian sengketa di pengadilan adalah terbuka, kaum bisnis lebih menyukai sengketa mereka diselesaikan tertutup, tanpa diketahui publik. Kedua, orang-orang bisnis menganggap hakim tidak selalu ahli berkaitan dengan sengketa yang timbul, sedangkan dalam mediasi, konsiliasi, dan arbitrase mereka dapat memilih mediator, konsiliator atau arbiter yang ahli. Ketiga, penyelesaian sengketa di pengadilan akan mencari pihak mana yang salah dan yang benar, sedangkan putusan penyelesaian sengketa di luar pengadilan akan dicapai melalui kompromi. ${ }^{9}$ Kunci dari segala keberhasilan penyelesaian sengketa di luar pengadilan adalah kehendak kedua belah pihak sendiri untuk menyelesaikan sengketa yang timbul di antara mereka. Kehendak bersama ini yang paling menentukan.

Sengketa itu normal, alamiah, kadang-kadang tidak dapat dihindarkan, karena tiap-tiap kita adalah unik, memiliki kepentingan yang berbeda dan nilai yang berbeda. Bila kita memandang sengketa sebagai suatu yang buruk, kita akan terus berpandangan bahwa sengketa tersebut adalah negatif. Ketakutan akan menolong kita dengan dua cara. Ia akan memberi sekumpulan energi yang kita perlukan untuk memusatkan pikiran untuk bagaimana mengatasi sengketa yang timbul dan ketakutan juga akan mengingatkan kita bahwa lawan juga merasa ketakutan yang sama seperti

8 M. Yahya Harahap, Beberapa Tinjauan Menegenai Sistem Peradilan dan Penyelesaian Sengketa (PT Citra Aditya Bakti 1997) 280-281.

$9 \quad$ Erman Rajagukguk, Penyelesaian Sengketa Alternatif: Negosiasi, Mediasi, Konsiliasi, Arbitrase (Fakultas Hukum Universitas Indonesia 2005) 1. 
yang kita rasakan. Akhirnya, melakukan pendekatan kerjasama untuk mengakhiri sengketa tidaklah berarti kita pihak yang kalah. ${ }^{10}$

Bila sengketa timbul, pertama-tama yang harus kita lakukan adalah ambil waktu untuk berpikir dan memusatkan pikiran (fokus) kepada sengketa yang terjadi. Sejauh mana sengketa itu timbul karena kita merasa diperlakukan tidak adil, walaupun kita telah berusaha sekuat mungkin menghindarinya. Sengketa telah terjadi, kita harus menerima realitas tersebut dan melihat diri kita sendiri, bakat dan kekuatan yang ada pada kita, untuk menyelesaikan sengketa tersebut. Langkah selanjutnya kita harus membuka mata dan hati untuk mengusahakan sebisa mungkin menyelesaikan sengketa tersebut dengan adil. Langkah ini termasuk tindakan selanjutnya, bertemu dengan pihak lawan, menyusun perencanaan. Akhirnya, visualisasi sengketa yang ada dan dengan bakat serta kepintaran yang ada pada kita, mencari jalan untuk menyelesaikannya. ${ }^{11}$

Abraham Lincoln, satu setengah abad yang lalu, sudah mengatakan untuk menghindarkan litigasi (penyelesaian melalui pengadilan). Walaupun ia mengatakan bahwa litigasi tersebut tetap penting dan jalan yang tepat untuk menyelesaikan sengketa, di mana diperlukan penemuan hukum yang baru untuk suatu hal yang penting, namun ia bisa disalahgunakan dalam suatu masyarakat yang menuntut haknya melalui pengadilan. Litigasi tersebut menghabiskan waktu dan uang, belum lagi risiko kalah dan perasaan tertekan menghadapi proses yang panjang. ${ }^{12}$

Oleh karenanya kita harus menyusun rencana lapangan yang praktis untuk menghadapi dan melakukan negosiasi, mediasi, arbitrase atau litigasi. Yang terakhir ini hanya dilakukan bila dikehendaki pihak lawan.

a. Tetapkan batas waktu (deadline) untuk menghindarkan sengketa berlarut-larut.

b. Atur pertemuan dengan pihak lawan untuk mengetahui dari tangan pertama tentang apa yang disengketakan. Pertemuan ini berguna untuk mendapatkan informasi yang diperlukan untuk mempersiapkan strategi negosiasi.

c. Susun strategi negosiasi untuk mencapai target yang kita inginkan dan konsesi yang dapat kita berikan kepada lawan, berikut alasan-alasan atau pembenaran usul-usul yang kita sampaikan dalam proses negosiasi.

d. Buatlah kontak pendahuluan dengan pihak lawan untuk menghindarkan pengharapan yang berlawanan dan mengajukan rencana dasar untuk pertemuan negosiasi.

\footnotetext{
10 Thomas E. Crowley, Settle It Out of Court (John Willey \& Sons 1994) 22-24.

11 Ibid. 27-32.

12 Ibid.
} 
e. Lakukan negosiasi langsung dengan pihak lawan memakai pendekatan yang bersahabat (collaborative approach).

f. Dalam hal negosiasi mengalami kegagalan, gunakan metode penyelesaian sengketa yang lain seperti mediasi, arbitrase atau litigasi (bila dikehendaki pihak lawan).

ADR sebagai salah satu cara untuk menyelesaikan sengketa sudah semenjak lama dikenal dalam berbagai kepercayaan dan kebudayaan. Berbagai fakta telah menunjukkan bahwa pda dasarnya mediasi bukan merupakan suatu metode yang asing dalam upaya menyelesaikan sengketa di tengah masyarakat. Hanya saja konteks pendekatan dan caranya yang lebih disesuaikan dengan budaya hukum (legal culture) ${ }^{13}$ setempat. Pengertian legal culture dimaksud adalah "people's attitudes toward law and the legal system-their beliefs, values, ideas and expectations. In other words, it is that part of the general culture which concerns the legal system". Seperti dalam masyarakat Cina tradisional secara sadar, mereka menerima ikatan-ikatan moral lebih dikarenakan pengaruh sanksi sosial daripada karena dipaksakan oleh hukum. Oleh karenanya clan, gilda dan kelompok terkemuka (gentry) menjadi institusi hukum yang informal dalam menyelesaikan sengketa antara mereka. Kepala clan, gilda dan tokoh masyarakat menjadi pengarah (mediator) dalam sengketa-sengketa yang timbul. Oleh karena itu, sangat masuk akal jika masyarakat Cina cenderung enggan menyelesaikan sengketa mereka di hadapan pengadilan, karena hubungan yang harmonis, bukan konflik, mendapatkan tempat yang tinggi di masyarakat. ${ }^{14}$

Tradisi Jepang bersamaan dengan Cina dan negara-negara Asia Timur lainnya yang sangat dipengaruhi oleh filosofi Confucian, memiliki kultur konsiliatori (conciliatory culture) di mana mediasi atau konsiliasi sudah sejak lama diakui sebagai mekanisme yang lebih cocok untuk menyelesaikan sengketa. Hal ini sejalan dengan kultur Jepang yang menekankan keharmonisan, yang pada gilirannya mempengaruhi sikap untuk mengutamakan mediasi dan konsolidasi, bukan litigasi. ${ }^{15}$

Sejarah gerakan Alternative Dispute Resolution dimulai ketika pada tahun 1976 Ketua Mahkamah Agung Warren Burger mempelopori ide ini pada suatu konferensi di Saint Paul, Mennesota Amerika Serikat. ${ }^{16}$ Ide ini disambut hangat oleh kaum akademisi, praktisi dan masyarakat. ${ }^{17}$ Hal ini

13 Lawrence Friedman, American Law: An Introduction (W.W. Norton \& Company 1984) 4.

14 Chung-Li Chang, The Chinese Century: On Their Role in $19^{\text {th }}$ Century Chinese Society (University of Washington Press 1955) 63. Lihat juga Kimberly K. Kovach, Mediation (Thompson West 2003) 17.

15 Yasunobu Sato, 'The Japanese Model of Dispute Processing' (Proceeding of the Roundtable Meeting, Law and Socio-Economic Change in Asia II, Bangkok, 2001) 152.

16 Jacqualine M. Nolan-Haley, Alternative Dispute Resolution in a Nutshell (West Publishing Co. 1992) 5

$17 \quad$ Ibid. 2. 
dilatarbelakangi oleh berbagai faktor gerakan reformasi pada awal tahun 1970, dimana saat itu banyak pengamat dalam bidang hukum dan masyarakat akademisi mulai merasakan adanya keprihatinan yang serius mengenai efek negatif yang semakin meningkat dari litigasi di pengadilan. Akhirnya ABA (American Bar Association) merealisasikan rencana itu dan selanjutnya menambahkan Komite ADR pada organisasi mereka diikuti dengan masuknya kurikulum ADR pada sekolah hukum di Amerika dan juga pada sekolah ekonomi. ${ }^{18}$ Dengan demikian, proses litigasi merupakan pilihan terakhir menyelesaikan sengketa, sebelumnya dilakukan perundingan di antara para pihak yang bersengketa, baik secara langsung maupun dengan menunjuk kuasa hukumnya, guna menghasilkan kesepakatan bersama yang menguntungkan kedua belah pihak. Jika proses perundingan ini tidak menghasilkan kesepakatan, baru para pihak akan menyerahkan kepada arbitrase atau pengadilan untuk menyelesaikan atau memutuskannya.

Legislasi yang dilaksanakan pada tahun 1960 memang menjamin adanya perlindungan terhadap individu dari hak-hak konsumen sampai hak sipil, namun perjuangan untuk mendapatkan hak-hak tersebut melalui sistem hukum litigasi tidaklah mudah dan cukup kompleks. Oleh karena itu, masyarakat mulai mencari alternatif lain dari pada adjudikasi pengadilan, di samping terjadinya penumpukan perkara atau court congestion, biaya proses peradilan yang tinggi dan waktu menunggu di pengadilan yang lama, telah menjadi cara hidup bagi orang Amerika untuk menyelesaikan sengketa dan kemudian mulai memilih sistem ADR bauk secara sukarela (voluntarily) maupun tidak sukarela (involuntarily). ${ }^{19}$ Sekarang ini, lembaga ADR yang sudah beroperasi dengan baik. Lembaga ADR komersial yang independen sudah tersebar hampir di seluruh negara bagian dengan staf yang siap memberikan pelayanan kepada masyarakat yang membutuhkan. Para negosiator, mediator maupun arbitratornya terdiri dari pengacara, praktisi hukum, pensiunan hakim, maupun para ahli dengan berbagai bidang disiplin ilmu.

Bagi kalangan masyarakat barat yang litigous minded (sedikit-sedikit berperkara) konsep ADR ini merupakan inovasi baru. Berbeda dengan masyarakat timur, pendekatan ala ADR adalah sebuah konsep yang dianggap bagian yang sudah lama ada dari kebudayaan mereka dalam konteks penyelesaian suatu konflik. ${ }^{20}$ Sehingga kemungkinan pemikiran untuk mengikutsertakan konsep ADR ini dalam sistem hukum nasionalnya akan lebih mudah. Masyarakat timur yang heterogen sudah terbiasa untuk mengambil keputusan ataupun menyelesaikan sengketa dengan jalan

Ibid. 6.

Ibid. 4.

Gary Goodpaster, A Guide to Mediation and Negotiation (Transnational Press Inc. 1977) Chapter 16. 
bermusyawarah. Dialog, musyawarah serta usaha pengakomodasian terhadap kepentingan semua pihak sebenarnya adalah inti dari konsep proses ADR ini. Konsep inilah yang kemudian diarahkan untuk menjadi cara menyelesaikan sengketa tetapi dengan menggunakan prinsip legalitas yang menjadi bagian dari sistem hukum.

\section{PENUTUP}

Berdasarkan pembahasan dapat disimpulkan beberapa hal sebagai berikut. Pertama, sengketa dalam pelaksanaan kontrak kerja sama tambang emas adalah kondisi yang tidak terelakkan karena potensi perbedaan kepentingan yang ada. Kedua, potensi terjadinya sengketa tersebut perlu diantisipasi melalui mekanisme penyelesaian sengketa yang memadai. Ketiga, arbitrase adalah pilihan yang tepat sebagai mekanisme penyelesaian sengketa untuk menyelesaikan sengketa dalam kontrak tambang emas di Indonesia.

\section{DAFTAR BACAAN}

\section{Buku}

Chang, Chung-Li, The Chinese Century: On Their Role in $19^{\text {th }}$ Century Chinese Society (University of Washington Press 1955).

Crowley, Thomas E., Settle It Out of Court (John Willey \& Sons 1994).
Friedman, Lawrence, American Law: An Introduction (W.W. Norton \& Company 1984).

Goodpaster, Gary, A Guide to Mediation and Negotiation (Transnational Press Inc. 1977).

Harahap, M. Yahya, Beberapa Tinjauan Menegenai Sistem Peradilan dan Penyelesaian Sengketa (PT Citra Aditya Bakti 1997).

Kovach, Kimberly K., Mediation (Thompson West 2003).

Mertokusumo, Sudikno, Mengenal Hukum, Suatu Pengantar (Liberty 1991).

Mulyadi, Kartini, dan Gunawan Widjaja, Perikatan Yang Lahir Dari Perjanjian (PT. Raja Grafindo Persada 2004).

Nolan-Haley, Jacqualine M., Alternative Dispute Resolution in a Nutshell (West Publishing Co. 1992).

Rajagukguk, Erman, Penyelesaian Sengketa Alternatif: Negosiasi, Mediasi, Konsiliasi, Arbitrase (Fakultas Hukum Universitas Indonesia 2005).

Subekti, Hukum Perjanjian (Intermasa 1998).

Suharnoko, Hukum Perjanjian, Teori dan Analisa Kasus (Prenada Media 2005).

\section{Makalah Seminar}

Yasunobu Sato, 'The Japanese Model of Dispute Processing' (Proceeding of the Roundtable Meeting, Law and Socio-Economic Change in Asia II, Bangkok, 2001). 
